\title{
Determinant of Attributes and Correlation of Safety Performance via Post Occupancy Evaluation (POE) for Low- Cost Housing
}

\author{
Husrul Nizam Husin ${ }^{1}$, Natasha Khalil2, Syahrul Nizam Kamaruzzaman ${ }^{*}$, Abdul Hadi \\ Nawawi ${ }^{4}$, Faridah Ismail 5 \\ ${ }^{1,2}$ Faculty of Architecture, Planning and Surveying, Universiti Teknologi MARA, Perak Branch, \\ 32610 Seri Iskandar, Perak, Malaysia \\ 3 Centre for Building, Construction \& Tropical Architecture (BuCTA), Faculty of Built \\ Environment, Universiti Malaya, 50603 Kuala Lumpur, Malaysia \\ ${ }^{4,5}$ Faculty of Architecture, Planning and Surveying, Universiti Teknologi MARA, 40450 Shah \\ Alam, Selangor, Malaysia
}

*syahrulnizam@um.edu.my

Received: 03 August 2017 Final Version Received: 18 January 2018

\begin{abstract}
The aspects in a completed residence or house should able to enhance the quality of a building as well as to provide safety to the occupants. It has become increasingly important to evaluate housing property for many reasons. The attempt to enhance the aspect of safety planning in developing low cost houses is still neglected and one of the reasons that may contribute to this factor is due to the low price value. Hence, this paper emphasizes the application of Post Occupancy Evaluation (POE) that incorporates participation from the occupants as a tool to assess the safety performance of the Malaysian low-cost housing. The main aim of this study is to develop a framework of POE integrated with safety elements for Malaysian LCH. The inspection survey and occupants' satisfaction survey were carried out to 24 low-cost housing projects located in the federal territory of Kuala Lumpur, Malaysia. The correlation result revealed that all attributes between the safety performance and the occupants' satisfaction had a significant relationship. This also manifests the occupants' feedbacks which were fed into the assessment of the housing safety performance.
\end{abstract}

Keywords: Safety performance; Post occupancy evaluation; Low-cost housing; Occupants' satisfaction; Correlation analysis

\section{INTRODUCTION}

Housing conditions constitute one of the most common quality of life indicators. The aspects in a completed residence or house should be able to enhance the quality of a building as well as to provide safety to the occupants; therefore, it has become increasingly important to evaluate housing properties for many reasons. As stated by Idrus and Ho (2008), residential and neighbourhood satisfactions are important indicators of housing quality and condition which affect individuals' quality of life. The factors, which determine their satisfaction levels, are essential inputs in monitoring the success of housing policies. Malaysia has been going through a rapid process of population growth and urbanisation for several years now. As announced in the recent Eleventh Malaysia Plan (Government of Malaysia, 2016), the government aimed to build one million affordable houses for the low-income groups. It is said that the construction of affordable housing for the citizens will be undertaken through collaboration between the state governments and private sectors through programmes including the national low-cost housing programmes, People's Housing Programme (PPR). Under the Malaysian Budget 2016 (Ministry of Finance Malaysia, 2016), it was said that an allocation of RM863 million will go to the Ministry of Urban Wellbeing, Housing, and Local Government (KPKT) to continue the initiatives to build 22,300 units of apartments and 9,800 units of terrace houses under the PPR. It is inevitable that the government encourages cooperative housing not only for the lower income groups, but also for the lower middle-income groups. Seeing the wavering economic situation, the emerging problem in housing property is the growing demand for better and safe housing. Therefore, it is increasingly important to evaluate housing property for many reasons. It needs to be set forth that poor quality of a building is much allied to the safety failures of 
the building. This assertion is supported by Yau (2006) that indefensible buildings with poor workmanship and low quality of materials also lead to building deterioration and poor aesthetical performance.

Stevenson and Leaman (2010) suggested that the evaluation of user perceptions and behaviour in relation to building performance in housing is an emerging research area. The review of the literature by Yau (2006) suggested that studies on housing safety should focus on the epidemiological relationship between the living built environment and safety hazards. As revealed by Shahrom and Zainol (2015) it is important to address the house design that not only minimize the risk of trips but also to be easily accessible and effective. The majority of low-cost housing (LCH) studies in Malaysia incorporated the occupants' feedback for determining their satisfaction on the layout design of the houses (including space, parking, units, and orientation) (Abdul Karim, 2008; Mohit, Ibrahim, \& Rashid, 2010; Mohit \& Nazyddah, 2010; Rashid, 2008; Salleh \& Yusof, 2006). Other major issues namely building materials and fittings, sanitary, and finishes were also considered for the quality of the housing (Goh \& Ahmad, 2012) and facilities (Mohit et al., 2010; Mohit \& Nazyddah, 2010; Rashid, 2008; Salleh \& Yusof, 2006).

Based on the literature review, it was found that there is a lack of research that has prioritised safety issues as the main aspect in the low-cost housing when using the POE method. The majority of researchers carried out the POE method (incorporating occupants' satisfaction and preferences) for architectural design and layout. The quality issues of the $\mathrm{LCH}$ programme were of concern to the previous studies but the majority of the studies did not relate quality factors towards building safety after the occupancy period of housing. It was found that only a few studies included social environment and integration issues with the variables such as noise, crime, accidents, security, and community relations. However, in, this research, safety does not pertain to social or environmental issues but for the technical attributes of the building, which affect the housing performance in respect of the safety of the occupants. Therefore, the assessment of safety in low-cost housing is highly related to the users' behaviour and occupants' feedback. As supported by Mustafa (2017), the purpose of a building is defeated if its users are not satisfied by the overall building performance.
The present research acknowledges the POE as a prominent tool to examine the safety performance in low-cost housing. Many previous studies (Collet da Graca et al., 2007; Gill et al., 2010; Goh \& Ahmad, 2012; Hassanain, 2007; Khalil \& Nawawi, 2008; Liu, 2003; Minami, 2007; Mumovic et al., 2009) showed significant results in optimising the performance of the building by applying POE as the research tool.

\section{INTEGRATING POST OCCUPANCY EVALUATION (POE) INTO SAFETY PERFORMANCE}

The importance of safety performance assessment of Malaysian low-cost housing is typically the criteria for judgement in the fulfillment of the functional and the occupants' needs. Aptly, the impact of strategies in dealing with the safety issues based on the building occupants' experiences needs to be measured. Such assessment is reliable by adopting Post Occupancy Evaluation (POE) as the approach and the best tool to assess safety performance in low-cost housing. Mustafa (2017) highlighted that POE provides enormous potential for improving the performance of a building when using occupants as a benchmark in evaluation. POE encompasses a comprehensive review of the building details covering the technical performance, users' satisfactions, project delivery process and recommendation for the action.

Multiple POE methods have been developed over the last 20 years, which demonstrates a huge potential in improving the quality of life, comfort and productivity of buildings (Nicol \& Roaf, 2005). Apart from reducing the financial and environmental costs, the output of POE entails beneficial recommendations, actions and measuring the building's effectiveness. As stated by Bordass \& Leaman (2005b), the POE exercise allows messages to be carried back to the relevant stakeholders and continue to repeat flawed prescriptions almost indefinitely. Feedback on building performance is usually obtained through POE (Preiser, 2001; Vischer, 2008) as the act of evaluating buildings in a systematic and rigorous manner after they have been built and occupied for some time (Gupta \& Chandiwala, 2010). The feedback forward cycle is the main key benefit of conducting POE in a building. Zimmerman \& Martin (2001) revealed that the over-arching benefit from conducting $\mathrm{POE}$ is the provision of valuable information to support the goal of continuous improvement. Bordass \& Leaman 
(2005) stated that feedback is "learning from what you are doing or from what you and others have done to understand where you are and to inform and improve what you are about to do". For residential projects, the occupants' feedback approach informs their day-to-day behaviour and enables them to have a better understanding of the interventions, including new technology, and the expected outcomes (Gupta \& Chandiwala, 2010).

\subsection{Performance of safety in Malaysian low-cost housing}

The significance of having a high-performance building is due to its ability to enhance the sustainability of the building. Pati et al. (2006) stated that articulating the expectations of owners and occupants is crucial in the assessment of building performance. In reviewing the aspects of the building performance, Hashim (2003) revealed that the physical aspects that relate to the building performance such as the finishing of the houses, materials used, design, and size of the houses are among the major complaints received pertaining to low-cost housing. The low-cost housing implies a lower standard of the housing; in trying to provide affordable housing, the standard of housing is always compromised. Structural failures are also associated with the major performance failures in low-cost housing. A survey carried out by Said and Juanil (2013) revealed that the first concern among housing residents pertaining to housing preferences is a sense of safety and security which can produce a quality environment.

As cited by Goh and Ahmad (2012), the Malaysian government was criticised by the Human Rights Commission of Malaysia in 2003 concerning the implementation of lowcost housing schemes due to the failure and issues relating to the physical safety of the occupants. Other issues that needed to be considered include the habitability, suitability, lack of maintenance, defects, and shoddy workmanship in the low-cost housing (Ismail, 2003). The poor quality of a building is much allied to its safety failures. This will become worse if it is left unattended with no maintenance action taken to solve the issues. As a result, the building will then be categorised as an unsafe building due to the poor quality of its physical condition. Goh and Ahmad (2012) in their research highlighted safety as the most important factor influencing the quality of $\mathrm{LCH}$. It was found that the provision of adjustable louvered windows carried the risk of glass panes falling from the higher floor if the catches do not function properly, thus, causing safety hazards to the occupants (Goh \& Ahmad, 2012). This was also supported by Muhamad Ariff (2011) who revealed that the owners of $\mathrm{LCH}$ were mainly concerned with making complaints about the structural defects of the building, which clearly affect the safety of the occupants in the dwellings.

Allied to the issues and scenarios in Malaysia, various evidence taken from The Star (dated 23rd July 2009) showed that the residents of $\mathrm{LCH}$ at Desa Mentari, Petaling Jaya, were worried about their safety and raised complaints about uneven pathways on the ground, voids underground beneath the concrete slabs, and collapse of the roof and roof accessories. Based on the review of safety issues in $\mathrm{LCH}$, in general, safety aspects can be viewed as the major concerns with the technical performance and building quality (Darkwa, 2006; Kowaltowski et al., 2006; Yau, 2006). Various studies have been conducted to review several issues pertaining to the technical performance and quality issues of $\mathrm{LCH}$ in Malaysia. The review of safety assessment, therefore, delineates both components of performance assessment and quality assessment as the safety factors.

\subsection{Justification of safety impact from the elements and attributes}

The context of safety in this research is delineated to hazards and conditions leading to physical, psychological or material harm to the health and well-being of the occupants that could lead to injury or death. Hence, to assess the building performance, it is vital to incorporate the safety criteria as the evaluation parameters. The safety attributes are also required in the checklist of inspection for further safety assessment, which is to be carried out in main survey. Therefore, the safety elements determined in this study are compiled and collected based upon the literature pertaining to the performance concept and the above reviewed safety assessment schemes. Ideally, the concept of safety performance is much related to the structural aspects of building (Abdul-Rahman, Kwan, \& Woods, 1999; Baird, Gray, Isaacs, Kernohan, \& McIndoe, 1996; Clift, 1996; Goh \& Ahmad, 2012; Liu, 2003), the provision of services in the building (Abdul-Rahman et al., 1999; CheAni, Ali, Tahir, Abdullah, \& Tawil, 2010; Goh \& Ahmad, 2012; Leung, Yu, \& Memari, 2016; 
Liu, 2003), the common area spaces ( Leung et al., 2016; Goh \& Ahmad, 2012; Kim, Yang, Yeo, \& Kim, 2005; Wang, Ho, \& Chen, 2005) and the building facilities and amenities (Leung et al., 2016; Goh \& Ahmad, 2012; Ho et al., 2008; Liu, 2003; Yau, 2006). The concern for the safety of the occupants that is inculcated in the fundamental theories of quality is much related to the quality of the architectural fittings (Abdul-Rahman et al., 1999; Goh \& Ahmad, 2012), quality of building materials (AbdulRahman et al., 1999; Goh \& Ahmad, 2012), the quality of the internal environment (Vilcekova et al., 2017;Goh \& Ahmad, 2012; Ho et al.,
2008; Wang et al., 2005) and the quality of workmanship (Abdul-Rahman et al., 1999; Goh $\&$ Ahmad, 2012). The listed safety elements are elaborated upon further to provide specific attributes for further safety assessment. The further outline of each safety element is compiled and collected from the literature and pilot articles to provide the attributes. The literature and pilot articles are selected based on the stipulated idea and scope that suit low-cost housing studies. The impact of safety from the safety elements and attributes to the context of safety in this research is organized into Table 1:

Table 1: Safety Impact from the outlined Safety Elements and Attributes

\begin{tabular}{|c|c|c|c|c|}
\hline Safety Elements & Source / Year & Theories/ Concept & $\begin{array}{c}\text { Safety Attributes / } \\
\text { Items }\end{array}$ & $\begin{array}{l}\text { The impact towards the } \\
\text { building and the } \\
\text { occupants' safety }\end{array}$ \\
\hline 1. Structural & $\begin{array}{l}\text { (Goh \& Ahmad, } \\
\text { 2012; Liu, 2003; } \\
\text { Abdul-Rahman } \\
\text { et al., 1999; } \\
\text { Baird et al., } \\
\text { 1996; Clift, } \\
\text { 1996) }\end{array}$ & $\begin{array}{l}\text { Structural } \\
\text { degradation and } \\
\text { deterioration causes } \\
\text { impact on } \\
\text { performance } \\
\text { quantification in } \\
\text { terms of collapse } \\
\text { safety. }\end{array}$ & $\begin{array}{l}\text { Substructure } \\
\text { (foundation, stump), } \\
\text { superstructure } \\
\text { (columns, beams, } \\
\text { floors), roof, masonry } \\
\text { walls, precast facade }\end{array}$ & $\begin{array}{l}\text { The potential for structural } \\
\text { damage is greatest in areas } \\
\text { underlain by structural } \\
\text { design, structural } \\
\text { materials and } \\
\text { workmanship of the } \\
\text { construction. Failures } \\
\text { include major cracks, } \\
\text { unset concrete works, } \\
\text { bulging, deflection or } \\
\text { sagging structural } \\
\text { elements. }\end{array}$ \\
\hline 2. Services & $\begin{array}{l}\text { ( Leung et al., } \\
\text { 2016;Abdul- } \\
\text { Rahman et al., } \\
\text { 1999; Che-Ani } \\
\text { et al., 2010; Goh } \\
\text { \& Ahmad, 2012; } \\
\text { Ho et al., 2008; } \\
\text { Wang et al., } \\
\text { 2005; Yau, } \\
\text { 2005) }\end{array}$ & $\begin{array}{l}\text { Characteristics of a } \\
\text { safe building include } \\
\text { proper installation of } \\
\text { electrical and } \\
\text { sanitary services and } \\
\text { evacuation of } \\
\text { occupants in } \\
\text { case of fire. }\end{array}$ & $\begin{array}{l}\text { Electrical wiring and } \\
\text { fittings, } \\
\text { communication } \\
\text { system, air- } \\
\text { conditioning system, } \\
\text { information } \\
\text { technology (IT) } \\
\text { system, fire } \\
\text { installation, lift, } \\
\text { escalators, building } \\
\text { automation, energy } \\
\text { supply system }\end{array}$ & $\begin{array}{l}\text { The provision of main } \\
\text { services must incorporate } \\
\text { suitable safety } \\
\text { management to avoid poor } \\
\text { installation and improper } \\
\text { fixing of the services. } \\
\text { Adequate means of escape } \\
\text { and fire fittings layout } \\
\text { enhances safety in } \\
\text { buildings. }\end{array}$ \\
\hline 3. Space & $\begin{array}{l}\text { ( Leung et al., } \\
\text { 2016; Goh \& } \\
\text { Ahmad, 2012; } \\
\text { Kim et al., 2005) }\end{array}$ & $\begin{array}{l}\text { Adequate space for } \\
\text { yard, corridor, has } \\
\text { appeared more } \\
\text { appropriate to } \\
\text { increase satisfaction } \\
\text { in quality and safety } \\
\text { for the occupants. }\end{array}$ & $\begin{array}{l}\text { Staircase, balcony, } \\
\text { dry yard, corridor, } \\
\text { etc. }\end{array}$ & $\begin{array}{l}\text { Design provision of space } \\
\text { is more concerns on any } \\
\text { improper access, space, } \\
\text { defective handrails, cracks } \\
\text { and potholes to common } \\
\text { area. }\end{array}$ \\
\hline 4. Amenities & $\begin{array}{l}\text { (Ho et al., 2008; } \\
\text { Kim et al., 2005; } \\
\text { Liu, 2003; Wang } \\
\text { et al., 2005; } \\
\text { Yau, 2006) }\end{array}$ & $\begin{array}{l}\text { Better ambience and } \\
\text { open space of } \\
\text { amenities, that is } \\
\text { free from crime and } \\
\text { vandalism help } \\
\text { mitigate safety } \\
\text { problems }\end{array}$ & $\begin{array}{l}\text { Vehicle parking, } \\
\text { ground parking } \\
\text { (motor), pavement, } \\
\text { walkway, dry yard, } \\
\text { playground, } \\
\text { recreation facilities, } \\
\text { toilets, guard house, } \\
\text { etc. }\end{array}$ & $\begin{array}{l}\text { Better ambience of } \\
\text { amenities address } \\
\text { improper function, } \\
\text { damages and improper } \\
\text { access and space that } \\
\text { enable to avoid safety } \\
\text { hazards that jeopardize the } \\
\text { building occupants. }\end{array}$ \\
\hline 5. Fittings & $\begin{array}{l}\text { ( Leung et al., } \\
\text { 2016; Goh \& } \\
\text { Ahmad, 2012; } \\
\text { Liu, 2003) }\end{array}$ & $\begin{array}{l}\text { Misalignment and } \\
\text { improper design on } \\
\text { of fittings also } \\
\text { constitutes the basis }\end{array}$ & $\begin{array}{l}\text { Door, window, roof } \\
\text { tiles, metal grilles, } \\
\text { security bars, } \\
\text { ironmongery, }\end{array}$ & $\begin{array}{l}\text { Examples are given for } \\
\text { better air movement } \\
\text { compared to casement or } \\
\text { top hung windows that }\end{array}$ \\
\hline
\end{tabular}




\begin{tabular}{|c|c|c|c|c|}
\hline & & $\begin{array}{l}\text { for the occurrence of } \\
\text { safety hazards. }\end{array}$ & handrails & $\begin{array}{l}\text { carry the risk of glass } \\
\text { falling. Thus, a proper } \\
\text { design of fittings could } \\
\text { avoid exposure to safety } \\
\text { hazards. }\end{array}$ \\
\hline 6.Materials & $\begin{array}{l}\text { ( Leung et al., } \\
\text { 2016; Abdul- } \\
\text { Rahman et al., } \\
\text { 1999; x) }\end{array}$ & $\begin{array}{l}\text { Proper selection of } \\
\text { materials } \\
\text { indemnifies the } \\
\text { quality of } \\
\text { specification }\end{array}$ & $\begin{array}{l}\text { Floor finishes, wall } \\
\text { finishes, ceiling } \\
\text { finishes, roof tiles, } \\
\text { door panels, window } \\
\text { panels, glass panels, } \\
\text { louvres }\end{array}$ & $\begin{array}{l}\text { Occurrence of defects due } \\
\text { to insufficient } \\
\text { consideration of the } \\
\text { accuracy and adequacy of } \\
\text { design detailing and } \\
\text { correct specification of } \\
\text { materials for safety and } \\
\text { security reasons. }\end{array}$ \\
\hline 7.Environment & $\begin{array}{l}\text { ( Vilcekova et } \\
\text { al., 2017; Goh \& } \\
\text { Ahmad, 2012; } \\
\text { Ho et al., 2008; } \\
\text { Wang et al., } \\
\text { 2005) }\end{array}$ & $\begin{array}{l}\text { Good surrounding } \\
\text { environment, such } \\
\text { as level of sound } \\
\text { pollution, water } \\
\text { pollution and air } \\
\text { pollution are } \\
\text { imperative factors } \\
\text { that influence a safe } \\
\text { environment in low- } \\
\text { cost flats. }\end{array}$ & $\begin{array}{l}\text { Ventilation, thermal } \\
\text { comfort, acoustic } \\
\text { comfort, visual } \\
\text { comfort, indoor } \\
\text { temperature, } \\
\text { cleanliness, noise } \\
\text { level, air movement, }\end{array}$ & $\begin{array}{l}\text { Avoidance of safety } \\
\text { hazards that imperil lives } \\
\text { in society and the } \\
\text { neighbourhood through } \\
\text { concern for the quality of } \\
\text { the indoor environment, } \\
\text { cross ventilation of air } \\
\text { movement, smoke escape } \\
\text { due to indoor activities. }\end{array}$ \\
\hline 8.Workmanship & $\begin{array}{l}\text { ( Goh \& Ahmad, } \\
\text { 2012; Abdul- } \\
\text { Rahman et al., } \\
\text { 1999; Baird et } \\
\text { al., 1996; Clift, } \\
\text { 1996; ) }\end{array}$ & $\begin{array}{l}\text { Delivering utmost } \\
\text { quality in } \\
\text { workmanship avoids } \\
\text { deterioration of } \\
\text { exposed surfaces }\end{array}$ & $\begin{array}{l}\text { Quality of fixings, } \\
\text { plastering works, } \\
\text { tiling works, painting } \\
\text { works, position of } \\
\text { fittings }\end{array}$ & $\begin{array}{l}\text { Any defects caused by the } \\
\text { substandard or } \\
\text { carelessness of the } \\
\text { operatives during the } \\
\text { course of construction. } \\
\text { These may constitute } \\
\text { further safety issues, that } \\
\text { includes improper fixings, } \\
\text { probability of water } \\
\text { seepage through fittings, } \\
\text { uneven tiles, incomplete } \\
\text { coverage of surfaces. }\end{array}$ \\
\hline
\end{tabular}

Table 1 shows that every element has different attributes or factors in respect of occupants' safety. Even though it shows that there are numerous attributes in each element, the suitable safety attributes for this study are divided into three (3) attributes for each safety element, as a basis of the initial construct for the framework. The attributes need to be outlined since they become the listed items that need to be measured in the safety inspection survey. The level of safety performance in the low-cost housing is benchmarked based on the attributes. The most important concept and process in $\mathrm{POE}$ is to describe the main considerations that should be evaluated as well as the actual method and the sequence in which it is to be carried out. A proper use of POE is then able to provide real information upon which decisions can be based, in which real information is the key to informing and improving the next project. Jacomit \& Granja (2011) found that as a typology is developed to satisfy families with different profiles, market research and POE are important to take care of their individual critical needs. Recent studies of
POE (for example: Agyekum et al.,2016; Hirning et al., 2012; Mustafa, 2017; Osei-poku, 2016) also supported that the fundamental concepts of POE stress the importance of feedback data from the building users. Therefore, it is important to incorporate occupants' feedback in POE as it benefits both the building and the residents. As POE studies emphasise the importance of feedback from the users, hence, their satisfaction is measured towards improving the raising current issues in the said building. Hence, the detailed methodology used by allocating POE into determining the safety criteria of low-cost housing is discussed in the next section.

\section{METHODOLOGY}

This research was conducted using the quantitative method by using questionnaires, and involved inspection and satisfaction surveys. The identification of the safety elements and attributes that needed to be incorporated into the framework was firstly gathered from the pilot survey using a 
questionnaire survey, involving industry practitioners that had previous or current experience in the LCH's development in Malaysia. The practitioners were from different backgrounds and designations such as architects, engineers, surveyors, and contractors who worked in organisations involving PPR housing development management, including the Ministry of Urban Wellbeing, Housing, and Local Government (KPKT), the Kuala Lumpur City Hall (DBKL), the Construction Industry Development Board (CIDB), and the Fire and Rescue Department Malaysia (BOMBA). The questionnaires were distributed to 80 industry practitioners as respondents and 50 respondents returned the completed questionnaire. It is shown as per Table 1, where the pilot survey had finalised 24 safety attributes that were categorised under 8 safety elements and 2 safety categories. Table 1 shows the finalised safety elements and attributes that were used in the SPIS and OSS. The building inspection survey named as the Safety Performance Inspection Survey (SPIS) was carried out to assess and determine the safety performance of the housing, while the satisfaction survey, named as the Occupants' Satisfaction Survey (OSS) was carried out to determine the users' level of satisfaction pertaining to the outlined safety elements and attributes. The results quantified from both surveys were presented using exploratory descriptive analysis and statistical tests of Cronbach's alpha and Spearman's rho (r) correlation. The Cronbach's alpha test was used to measure the internal consistency of the questions in the questionnaire of the preliminary and main surveys. Spearman rho correlation was used to determine the relationship between the safety performance level and satisfaction level of the occupants in terms of the level of significance. A statistical analysis programme, namely the SPSS version 20, was used for this purpose.

Table 2: The finalised safety elements and safety attributes from the pilot survey

\begin{tabular}{|c|c|c|c|}
\hline SAFETY CATEGORY & SAFETY ELEMENTS & & SAFETY ELEMENTS \\
\hline \multirow{12}{*}{ Performance $(\mathrm{P})$} & \multirow{3}{*}{ Structural (ST) } & ST1 & Column / beam \\
\hline & & ST2 & Roof \\
\hline & & ST3 & Slabs \\
\hline & \multirow{3}{*}{ Services (SR) } & SR1 & Electrical Services \\
\hline & & SR2 & Plumbing System \\
\hline & & SR3 & Fire System \\
\hline & \multirow{3}{*}{ Space (SP) } & SP1 & Corridor \\
\hline & & SP2 & Staircase \\
\hline & & SP3 & Balcony \\
\hline & \multirow{3}{*}{ Amenities (AM) } & AM1 & Playground \\
\hline & & AM2 & Vehicle Parking \\
\hline & & AM3 & Lift \\
\hline \multirow{12}{*}{ Quality (Q) } & \multirow{3}{*}{ Fittings (FT) } & FT1 & Door / window \\
\hline & & FT2 & Security bar \\
\hline & & FT3 & Sanitary fittings \\
\hline & \multirow{3}{*}{ Materials (MR) } & MR1 & Floor finishes \\
\hline & & MR2 & Wall finishes \\
\hline & & MR3 & Ceiling finishes \\
\hline & \multirow{3}{*}{ Environment (EV) } & EV1 & Internal ventilation \\
\hline & & EV2 & Indoor temperature \\
\hline & & EV3 & Visual obstruction \\
\hline & \multirow{3}{*}{ Workmanship (WS) } & WS1 & Plastering works \\
\hline & & WS2 & Tiling works \\
\hline & & WS3 & Painting works \\
\hline
\end{tabular}

\section{ANALYSIS OF FINDINGS}

The analysis of the main survey presented in three parts; i) The result of SPIS, ii) The result of OSS, and iii) The correlation of the SPIS and OSS. The first part described the analysis of safety performance level for each safety element and attribute. The second part of the analysis revealed the level of occupants' satisfaction towards the safety attributes. Finally, the last part of this analysis revealed the findings of correlation between the safety performance scale and the occupants' satisfaction level based on the similar safety 
attributes for the sample of housing units. The sampling of the study was derived from the overall population of the housing listed by the Kuala Lumpur City Hall (DBKL), which comprised of 28,970 housing units, based on the 24 low-cost housing projects in Malaysia, namely the PPR. The cluster sampling was used to select low-cost houses (LCH) from the housing list provided by the DBKL. The sample size of housing was determined using the formula developed by Krejcie and Morgan (1970). In order to obtain samples of respondents for the questionnaire survey, a targeted number of respondents was first determined prior to distributing the questionnaire survey since the units and blocks for each residential area vary. The questionnaires were distributed to the occupants of the selected sample buildings. The sample size was determined using the formula by Krejcie and Morgan (1970). Since the drawn up population was similar to the SPIS, the sample size for OSS was also 380. Therefore, both SPIS and OSS were carried out in a parallel sample size, i.e. 380 samples.
Table 3 lists the housing projects of the 24 PPRs. PPR is a Malaysian government programme that was introduced to accommodate and meet the needs of all slum dwellings for low-income earners, which started during the First Malaysian Plan (year 1966 1970) as the government's commitment to the needs of PPR. The PPRs are located in the federal territory of Kuala Lumpur. Kuala Lumpur is the capital and the largest city of Malaysia covering a land area of $244 \mathrm{sq} \mathrm{km} \mathrm{(94}$ sq mi), with a population of 1.63 million according to census projections in 2010 (Junaidi et al., 2012). With the help and information from the Kuala Lumpur City Hall (DBKL), most of the complaints relating to safety issues were compiled from the 24 PPRs. Most of the PPR tenants occupied the housing on a rental basis and only a segment of the tenants bought and own the units. The records given by the DBKL also showed that the housing projects were handed over to the tenants at the beginning of 2002 to 2010 and therefore, the occupancy period of the housing ranged from 2 to 10 years.

Table 3: Information of the PPR housing projects

\begin{tabular}{|c|l|c|c|}
\hline No. & \multicolumn{1}{|c|}{ Housing Projects } & Units & Blocks \\
\hline 1 & PPR Kg. Muhibbah, Jalan Puchong & 2,844 & 9 \\
\hline 2 & PPR Malaysia Permai (PPR Raya Permai) & 1,264 & 4 \\
\hline 3 & PPR Sg. Besi (PPR Desa Petaling) & 632 & 2 \\
\hline 4 & PPR Pudu Hulu & 948 & 3 \\
\hline 5 & PPR Seri Malaysia & 632 & 2 \\
\hline 6 & PPR Jln. Lapangan Terbang Lama Fasa 1 (PPR Seri Alam) & 660 & 5 \\
\hline 7 & PPR Jln Cochrane (PPR Laksamana \& PPR Perkasa) & 1,620 & 5 \\
\hline 8 & PPR Jln. Lapangan Terbang Lama Fasa 2 (PPR Seri Alam 2) & 920 & 7 \\
\hline 9 & PPR KL Linear City 1 (PPR Seri Anggerik) & 316 & 1 \\
\hline 10 & PPR KL Linear City Ii Fasa 1 (PPR Pantai Ria) & 1,264 & 4 \\
\hline 11 & PPR Lembah Pantai, Kerinchi & 1,896 & 6 \\
\hline 12 & PPR KL Linear City Ii Fasa 2 (PPR Seri Cempaka) & 632 & 2 \\
\hline 13 & PPR Salak Selatan & 632 & 2 \\
\hline 14 & PPR Kg. Limau, Pantai Dalam & 632 & 2 \\
\hline 15 & PPR Taman Intan Baiduri & 1,834 & 6 \\
\hline 16 & PPR Taman Wahyu I (PPR Beringin) & 1,896 & 6 \\
\hline 17 & PPR Pekan Batu & 632 & 2 \\
\hline 18 & PPR Taman Wahyu II (PPR Wahyu) & 948 & 3 \\
\hline 19 & PPR Kg Batu Muda (SPNB) & 2,132 & 7 \\
\hline 20 & PPR Pekan Kepong & 948 & 3 \\
\hline 21 & PPR Ampang Hilir (PPR Hiliran Ampang) & 948 & 3 \\
\hline 22 & PPR Kg. Baru Air Panas & 2,528 & 8 \\
\hline 23 & PPR Sg. Bonus, Air Jernih & $\mathbf{2 8 , 9 7 0}$ & $\mathbf{9 9}$ \\
\hline 24 & PPR Seri Semarak & 2 \\
\hline & & Total & 50 \\
\hline
\end{tabular}




\subsection{Results of Safety Performance Inspection Survey (SPIS)}

In this section, the SPIS was carried out to the housing projects, with the help of nominated professional building surveyors and safety assessors. To recap, there were 24 safety attributes finalised from the result of the pilot survey and the list was incorporated in the SPIS form. The safety rating of each attribute was assessed in accordance to the five numerical Likert-scale (1- very poor; 5 - very good) in terms of its safety conditions. The description of scale value was adapted from the previous safety performance schemes; CSP1Matrix (Che-Ani et al., 2010) and Housing Performance Evaluation Model (Kim et al., 2005). Table 4 shows the mean results of the SPIS:

Table 4: Mean Rank score for Safety Performance Score (SPS)

\begin{tabular}{|c|c|c|c|}
\hline \multirow{2}{*}{ Attributes Of Safety Performance } & \multicolumn{3}{|c|}{ Statistical Result } \\
\hline & Sum $\left(\sum x\right)$ & Mean $(\mu)$ & Standard Deviation (s) \\
\hline 1. Security bar / metal grille & 1428 & 3.76 & 0.4756 \\
\hline 2. Column / Beam & 1391 & 3.66 & 0.5839 \\
\hline 3. Door / window & 1390 & 3.66 & 0.6447 \\
\hline 4. $\quad$ Roof & 1366 & 3.59 & 0.5937 \\
\hline 5. Plumbing system & 1336 & 3.52 & 0.6715 \\
\hline 6. Sanitary fittings & 1301 & 3.42 & 0.7528 \\
\hline 7. $\quad$ Slabs & 1292 & 3.40 & 0.6682 \\
\hline $\begin{array}{ll}\text { 8. } & \text { Tiling works }\end{array}$ & 1263 & 3.32 & 0.6316 \\
\hline 9. $\quad$ Floor finishes & 1254 & 3.30 & 0.6926 \\
\hline 10. Internal ventilation & 1251 & 3.29 & 0.5687 \\
\hline 11. Wall finishes & 1245 & 3.28 & 0.7005 \\
\hline 12. Corridor & 1245 & 3.28 & 0.5136 \\
\hline 13. Indoor temperature & 1241 & 3.27 & 0.7046 \\
\hline 14. Plastering works & 1212 & 3.19 & 0.7050 \\
\hline 15. Visual obstruction & 1201 & 3.16 & 0.7140 \\
\hline 16. Balcony & 1174 & 3.09 & 0.5878 \\
\hline 17. Painting works & 1165 & 3.07 & 0.6319 \\
\hline 18. Staircase & 1151 & 3.03 & 0.6389 \\
\hline 19. Fire system & 1137 & 2.99 & 0.6948 \\
\hline 20. Electrical services & 1132 & 2.98 & 0.8805 \\
\hline 21. Playground & 1128 & 2.97 & 0.6367 \\
\hline 22. Ceiling finishes & 1106 & 2.91 & 0.8518 \\
\hline 23. Vehicle Parking & 1073 & 2.82 & 0.7065 \\
\hline 24. Lift & 722 & 1.90 & 0.6379 \\
\hline
\end{tabular}

Table 4 shows the summated scores, mean scores, and standard deviation that represent the distribution of the performance scores around the mean. The obtained mean values ranged from the lowest order of mean $=1.90$ ( $s=0.6379)$ to the highest order of mean $=3.76$ $(s=0.4756)$. These results indicated a smaller dispersion of tabulation and showed a higher degree of consistency for all performance scores. The results revealed that the safety performance of all attributes was generally average; neither poor nor good. Thus, this illustrated that the occurrence of technical and quality performance issues in low-cost housing needed a thorough improvement by only considering the critical safety attributes that attained a mean score ranging from 0.00 to
2.00 which were; Lift (mean=1.90), Vehicle Parking (mean=2.82), Ceiling finishes (mean=2.91), Playground (mean=2.97), Fire system (mean=2.99), and Electrical services (mean=2.98).

\subsection{Results of Occupants' Satisfaction Survey (OSS)}

Section B of the questionnaire required the respondents to rate their satisfaction level for all safety attributes under the safety category which were i) performance and ii) quality. The safety attributes were similar to the attributes that were listed in the safety performance survey (SPIS). The respondents rated their satisfaction level based on the five numerical 
Likert-scale; "1" (Very dissatisfied), "2" (Dissatisfied), "3" (Moderately satisfied), "4" (Satisfied), and "5" (Very satisfied). Table 5 shows the mean results of the occupants' satisfaction level:

Table 5: Mean Rank score for Occupants' Satisfaction Score (OSS)

\begin{tabular}{|c|c|c|c|}
\hline \multirow{2}{*}{ Attributes Of Safety Performance } & \multicolumn{3}{|c|}{ Statistical Result } \\
\hline & Sum $\left(\sum x\right)$ & Mean $(\mu)$ & Standard Deviation (s) \\
\hline 1. Security bar / metal grille & 1380 & 3.63 & 0.6745 \\
\hline 2. Column / beam & 1354 & 3.59 & 0.6706 \\
\hline 3. Door / window & 1344 & 3.56 & 0.7049 \\
\hline 4. Roof & 1336 & 3.55 & 0.6632 \\
\hline 5. Slabs & 1286 & 3.44 & 0.7101 \\
\hline 6. $\quad$ Plumbing System & 1292 & 3.43 & 0.7893 \\
\hline 7. $\quad$ Sanitary fittings & 1289 & 3.39 & 0.7559 \\
\hline 8. $\quad$ Floor finishes & 1255 & 3.30 & 0.6971 \\
\hline 9. Wall finishes & 1250 & 3.30 & 0.7151 \\
\hline 10. Tiling works & 1235 & 3.28 & 0.6861 \\
\hline 11. Indoor temperature & 1235 & 3.28 & 0.7389 \\
\hline 12. Internal ventilation & 1240 & 3.27 & 0.6567 \\
\hline 13. $\quad$ Corridor & 1217 & 3.25 & 0.6149 \\
\hline 14. Plastering works & 1192 & 3.21 & 0.7169 \\
\hline 15. Visual obstruction & 1188 & 3.14 & 0.7950 \\
\hline 16. Vehicle Parking & 1168 & 3.13 & 0.7269 \\
\hline 17. Painting works & 1175 & 3.12 & 0.6897 \\
\hline 18. Balcony & 1151 & 3.11 & 0.6553 \\
\hline 19. Ceiling finishes & 1177 & 3.11 & 0.8226 \\
\hline 20. $\quad$ Fire System & 1170 & 3.10 & 0.7491 \\
\hline 21. Electrical Services & 1161 & 3.08 & 0.9045 \\
\hline 22. $\quad$ Staircase & 1122 & 3.01 & 0.6975 \\
\hline 23. $\quad$ Balcony & 1074 & 2.85 & 0.7895 \\
\hline 24. $\quad$ Lift & 767 & 2.05 & 0.7390 \\
\hline
\end{tabular}

Table 5 shows the summated scores, mean scores, and standard deviation that represent the distribution of the occupants' satisfaction level around the mean. The obtained mean values ranged from the highest order of mean $=3.63$ $(\mathrm{s}=0.6745)$ to the lowest order, mean $=2.05$ $(s=0.7390)$. These results indicated a smaller dispersion of tabulation that showed a higher degree of consistency for all performance scores. This revealed that the occupants' satisfaction with all the attributes generally reached average satisfaction that was neither being satisfied nor dissatisfied. Even though the valid case was not similar with the results of the SPIS (due to several incomplete responses from the respondents), the attributes were closely associated with the safety performance results obtained from the inspection survey. It was found that a similar attribute, namely the lift, was ranked as having the lowest satisfaction by the occupants, which was associated with the similar attribute ranking as the lowest safety performance in the inspection survey. Since the majority of the attributes attained mean ranking scores ranging from 3.00 to 3.99 (moderate to satisfied), many improvements need to be taken to enhance the residents' satisfaction concerning their safety in these areas.

\subsection{Correlation Results of Safety Performance and Occupants' Satisfaction}

The final section of the analysis illustrated the correlation between Safety Performance Scale and Occupants' Satisfaction Level. The Spearman rho ( $r$ ) was used in the analysis since both variables consisted of ordinal scales derived from a random sampling of the housing units and respondents. The correlation test was carried out to investigate whether there was a significant relationship between the safety performance level and occupants' satisfaction level with similar safety attributes. This provides the reliability of using POE as the benchmark for safety performance assessment in the low-cost housing. The research and null hypotheses of the study are as follows:

$H_{l}=$ There is a significant relationship between the safety performance of the low-cost housing, 
and the occupants' satisfaction with regard to the safety performance.

$H_{0}=$ There is no relationship between the safety performance of the low-cost housing, and the occupants' satisfaction with regard to the safety performance.

According to Chua (2008), the result of the Spearman correlation shows the strength of the relationship of two variables by referring to its correlation coefficient value of Spearman rho (r). The significant level of the variables was tested with a two-tailed, with a significant correlation value at .01 level (2-tailed). The correlation analysis was reported in two divisions of the safety categories namely, performance and quality categories. There were twelve safety attributes under each category validated from the preliminary survey. The analysis of the correlation used the statistical software programme SPSS (Statistical Packages for the Social Sciences, versions 16.00). The hypotheses were statistically tested with a two-tailed alpha level of 0.05 .

Table 6: Correlation Result for Safety Attributes under Performance Category

\begin{tabular}{|c|c|c|c|c|c|c|c|c|c|c|c|c|}
\hline $\begin{array}{c}\text { ATTRIBUTES } \\
\text { FOR SAFETY } \\
\text { PERFORMANCE }\end{array}$ & $\begin{array}{l}\text { Column } \\
\text { / Beam }\end{array}$ & Roof & Slabs & $\begin{array}{l}\text { Electrical } \\
\text { services }\end{array}$ & $\begin{array}{l}\text { Plumbing } \\
\text { system }\end{array}$ & $\begin{array}{l}\text { Fire } \\
\text { system }\end{array}$ & Corridor & Staircase & Balcony & $\begin{array}{l}\text { Play } \\
\text { ground }\end{array}$ & $\begin{array}{l}\text { Vehicle } \\
\text { parking }\end{array}$ & Lift \\
\hline $\begin{array}{c}\text { Correlation } \\
\text { Coefficient (r) }\end{array}$ & $.662^{* *}$ & $.714^{* *}$ & $.670^{* *}$ & $.633^{* *}$ & $.625^{* *}$ & $.703^{* *}$ & $.624^{* *}$ & $.645^{* *}$ & $.647^{* *}$ & $.493^{* *}$ & $.297^{* *}$ & $.434^{* *}$ \\
\hline Sig. (2tailed) & .000 & .000 & .000 & .000 & .000 & .000 & .000 & .000 & .000 & .000 & .000 & .000 \\
\hline $\begin{array}{l}\text { ATTRIBUTES } \\
\text { FOR } \\
\text { OCCUPANTS' } \\
\text { SATISFACTION }\end{array}$ & $\begin{array}{l}\text { Column } \\
\text { / Beam }\end{array}$ & Roof & Slabs & $\begin{array}{l}\text { Electrical } \\
\text { services }\end{array}$ & $\begin{array}{l}\text { Plumbing } \\
\text { system }\end{array}$ & $\begin{array}{l}\text { Fire } \\
\text { system }\end{array}$ & Corridor & Staircase & Balcony & $\begin{array}{l}\text { Play } \\
\text { ground }\end{array}$ & $\begin{array}{l}\text { Vehicle } \\
\text { parking }\end{array}$ & Lift \\
\hline
\end{tabular}

Table 7: Correlation Coefficient for Safety Attributes under Quality Category

\begin{tabular}{|c|c|c|c|c|c|c|c|c|c|c|c|c|}
\hline $\begin{array}{c}\text { ATTRIBUTES } \\
\text { FOR SAFETY } \\
\text { PERFORMANCE }\end{array}$ & $\begin{array}{c}\text { Door / } \\
\text { Window }\end{array}$ & $\begin{array}{l}\text { Security } \\
\text { bar }\end{array}$ & $\begin{array}{c}\text { Sanitary } \\
\text { Fittings }\end{array}$ & $\begin{array}{l}\text { Floor } \\
\text { Fin. }\end{array}$ & $\begin{array}{l}\text { Wall } \\
\text { Fin. }\end{array}$ & $\begin{array}{c}\text { Ceili } \\
\text { ng } \\
\text { Fin. }\end{array}$ & $\begin{array}{c}\text { Internal } \\
\text { Vent. }\end{array}$ & $\begin{array}{l}\text { Indoor } \\
\text { Temp. }\end{array}$ & $\begin{array}{l}\text { Visual } \\
\text { Obstruction }\end{array}$ & $\begin{array}{l}\text { Plastering } \\
\text { Works }\end{array}$ & $\begin{array}{c}\text { Tiling } \\
\text { Works }\end{array}$ & $\begin{array}{l}\text { Painting } \\
\text { Works }\end{array}$ \\
\hline $\begin{array}{c}\text { Correlation } \\
\text { Coefficient (r) }\end{array}$ & $.592^{* *}$ & $.595^{* *}$ & $.722^{* *}$ & $.664^{* *}$ & $\begin{array}{c}682^{*} \\
*\end{array}$ & $.581^{*}$ & $.689^{* *}$ & $.654^{* *}$ & $.682^{* *}$ & $.652^{* *}$ & $.657^{* *}$ & $.703^{* *}$ \\
\hline Sig. (2tailed) & .000 & .000 & .000 & .000 & .000 & .000 & .000 & .000 & .000 & .000 & .000 & .000 \\
\hline $\begin{array}{c}\text { ATTRIBUTES } \\
\text { FOR } \\
\text { OCCUPANTS' } \\
\text { SATISFACTION }\end{array}$ & $\begin{array}{l}\text { Door / } \\
\text { Window }\end{array}$ & $\begin{array}{l}\text { Security } \\
\text { bar }\end{array}$ & $\begin{array}{l}\text { Sanitary } \\
\text { Fittings }\end{array}$ & $\begin{array}{l}\text { Floor } \\
\text { Fin. }\end{array}$ & $\begin{array}{l}\text { Wall } \\
\text { Fin. }\end{array}$ & $\begin{array}{l}\text { Ceili } \\
\text { ng } \\
\text { Fin. }\end{array}$ & $\begin{array}{l}\text { Internal } \\
\text { Vent. }\end{array}$ & $\begin{array}{l}\text { Indoor } \\
\text { Temp. }\end{array}$ & $\begin{array}{l}\text { Visual } \\
\text { Obstruction }\end{array}$ & $\begin{array}{l}\text { Plastering } \\
\text { Works }\end{array}$ & $\begin{array}{l}\text { Tiling } \\
\text { Works }\end{array}$ & $\begin{array}{l}\text { Painting } \\
\text { Works }\end{array}$ \\
\hline
\end{tabular}

Tables 6 and 7 show the results of the Spearman correlation test between Safety Performance Level and Occupants' Satisfaction Level as the tested variables. Majority of the attributes of the occupants' satisfaction level were positively correlated with the safety performance levels in the housing unit. For the category of "performance", the correlation coefficient of the attributes indicated an average and strong correlation value. The highest correlation coefficient indicated for the attribute was Roof, with a significant value of $r=0.714$. The attributes that were categorised as "average" in terms of relationship strength were column/beam, slabs, electrical services, plumbing system, fire system, corridor, staircase, and balcony, with a coefficient range from 0.624 to 0.703 . All of the variables had a significant relationship (Sig. $=0.000)$, even though some of the variables had a weak correlation strength (Playground, $r=0.493$, Vehicle Parking, $r=0.297$,
Lift, r=0.434). Despite having a weak correlation, these attributes had very significant relationships and supported the research hypothesis. It was also illustrated that the null hypothesis was successfully rejected, and the study indicated a significant relationship between the attributes for both variables. Almost similar to the result as in the Performance category, the majority of the attributes in the category of "Quality" was positively correlated with the safety performance level. In terms of correlation strength, only the variation of Sanitary Fittings had a strong relationship, with $r=0.722$. The rest of the attributes; door/window, security bar, floor, wall and ceiling finishes, internal ventilation, indoor temperature, visual obstruction, and plastering, tiling, and painting works, were categorised as average strength with coefficient values ranging from 0.582 to 0.703 . 
Despite the findings resulted in a moderate correlation strength, it was found that all of the variables had a significant relationship (Sig.=.000). The lowest correlation coefficient, indicated based on the result, was Ceiling Finishes with $r=0.581$. This result had rejected the null hypothesis. Therefore, there was a significant relationship between the two variables. Hence, this result supported the research hypothesis. Both results in the above correlation analysis showed significant relationships between both variables. Since the correlation only provided the value of coefficient and strength of relationship, predictions against the causes and consequences had to be defined from the analysis. The researcher predicted that the level of occupants' satisfaction depended upon the level of safety performance in their housing unit. The correlation result is vital to glimpse the effectiveness of POE as the tool of assessing the performance of safety in the lowcost housing. The convincing correlation results confirmed the relevance of POE as the safety performance tool for this study.

\section{DISCUSSION OF FINDINGS}

The results of the correlation analysis of all attributes were presented in a separate tabulation under the category of Performance (P) and Quality (Q). To recap, the correlation test was conducted to determine the relationship between the safety performance level and occupants' satisfaction level with similar safety attributes. If the relationship is significant, this generally provides that safety performance of the housing reflects the satisfaction level of the occupants. Thus, it presents the reliability of using POE as the benchmark for safety performance assessment in the low-cost housing. In this research, all attributes for both safety performance and occupants' satisfaction were positively correlated. The highest correlation coefficient was sanitary fittings, with $r=0.722$ followed by roof with $r=0.714$. Roof is significant as it is highly related to the users' safety while defective roof creates the tendency of safety hazards. The result is parallel with the inspection carried out in a study by Olanrewaju (2010) which revealed saturation by water from defective roof can cause serious deterioration in ceiling and wall. The structural degradation and deterioration may have an impact on the performance quantification of a building in terms of collapse safety. This is also supported by Ali et al., (2010) who emphasised a continuous inspection of structural stability for the high-rise housings to ensure the occupants' safety.
The result of the significance level in the correlation analysis successfully rejected the null hypothesis. In other words, there was a significant relationship between the occupants' satisfaction and safety performance. This result suggested that the occupants' satisfaction depended upon the safety performance in the housing. In the concept of POE, the feedback from end-users is important to evaluate the whole safety performance of low-cost housing (Eley, 2001). In this research, the result indicated that the information from the housing occupants on the performance of safety in the low-cost housings helped to support the result of the safety evaluation. This is in line with the concept of POE where the criteria for judgement are the fulfilment of the functional programme and occupants' needs (Leung et al., 2016; Mustafa, 2017; Zimmerman \& Martin, 2001). The correlation between the occupants' satisfaction and safety performance was measured to improve the current safety performance raised in the building.

The evaluation by the professional assessors in building safety is a normal procedure for building assessment. However, without getting the current information from the building users or occupants, it does not reflect the vital concept in POE, which is the user's feedback. The main consideration of POE is to get essential information from the users to reflect the importance of safety. The post-handover period is the most neglected stage of construction, often looked upon as a nuisance and distraction (Way \& Bordass, 2005).This justifies the reason for carrying out both of the main surveys, which are the safety performance inspection survey (SPIS) and the occupants' satisfaction survey (OSS). The result of the correlation proved the importance of both surveys as all attributes were positively correlated and had significant values. Previous researchers agreed that statements based on the findings showed that there was a direct link between the building and its users as factors in building performance (Karemera et al., 2003; Khalil \& Husin, 2009; Pitt \& Tucker, 2008). This also confirmed the relevance of POE as the safety performance tool to fit the objectives of this study.

\section{CONCLUSION}

By using POE as a tool for the evaluation of safety performance in low-cost housing, it is necessary to incorporate all of the phases in the survey instrument. The outcome of the Preliminary Survey and Semi-Structured Interviews confirmed the inputs of the safety elements that needed to be integrated into the 
POE tools. The outcome of the Main Surveys involving Safety Performance Inspection Survey (SPIS) and Occupants' Satisfaction Survey (OSS) supported the rationale for incorporating the occupants' participation in assessing the safety performance level of the housing. This research utilizes POE as the safety performance tool that incorporates specific human needs in the housing evaluation. Thus, all the results from both the Preliminary and Main Surveys confirmed the relevance of using POE as the safety performance tool. This research has introduced a new dimension for safety performance assessment in the low-cost housing using the Post Occupancy Evaluation (POE) as the safety performance tool. By allowing participation of users for safety assessment, it stresses the fundamental concept of POE by highlighting the importance of obtaining feedback from the building occupants. Receiving complaints from the occupants after the occurrence of incidents are demarcated as a reactive approach while the current inspection survey does not incorporate the occupants' participation. Feedback from occupants is not a routine of building assessment during occupancy, hence, using POE is generally a new dimension of safety performance in Malaysian low-cost housing.

\section{ACKNOWLEDGEMENTS}

The authors wish to acknowledge the support grant in performing this study under the Exploratory Research Grant Scheme (ERGS) Phase 1/2011 funded by the Ministry of Higher Education Malaysia (MOHE) and also Universiti Teknologi MARA, Perak Branch, Seri Iskandar, Malaysia.

\section{REFERENCES}

Abdul-Rahman, H., Kwan, C. L., \& Woods, P. C. (1999). Quality function deployment in construction design : application in low-cost housing design. International Journal of Quality \& Reliability Management, 16(6), 591-605.

Abdul Karim, H. (2008). The Satisfaction of Residents on Community Facilities in Shah Alam , Malaysia. Asian Social Science, 4(11), 131-137.

Agyekum, K., Ayarkwa, J., \& Amoah, P. (2016). Post Occupancy Evaluation of Postgraduate Students' Hostel, 7(1), 97-104.

Ali, A. S., Kamaruzzaman, S. N., Sulaiman, R., \& Peng, Y. C. (2010). Factors affecting housing maintenance cost in Malaysia. Journal of Facilities Management, 8(4), 285298. http://doi.org/10.1108/14725961011078990

Baird, G., Gray, J., Isaacs, N., Kernohan, D., \& McIndoe, G. (1996). Building Evaluation Technique. McGraw-Hill: New York, NY, USA.

Bordass, B., \& Leaman, A. (2005). Making feedback and post-occupancy evaluation routine 3: Case studies of the use of techniques in the feedback portfolio. Building Research \& Information, 33(4), 361-375. http://doi.org/10.1080/09613210500162032

Che-Ani, A. I., Ali, A. S., Tahir, M. M., Abdullah, N. A. G., \& Tawil, N. M. (2010). The Development of a Condition Survey Protocol (CSP) 1 Matrix for Visual Building Inspection. In The Construction, Building and Real Estate Research Conference of the Royal Institution of Chartered Surveyors (COBRA2010), 2-3 September 2010 (pp. 822). Dauphine Université, Paris.

Chua, Y. P. (2008). Asas Statistik Penyelidikan: Analisis Data Skala Ordinal dan Skal Nominal (Kaedah dan Statistik Penyelidikan. Buku 3). McGraw Hill, Malaysia.

Clift, M. (1996). Building quality assessment (BQA) for offices. Structural Survey, 14(2), 22-25.

Collet da Graca, V. A., Kowaltowski, D. C. C. K., \& Petreche, J. R. D. (2007). An evaluation method for school building design at the preliminary phase with optimisation of aspects of environmental comfort for the school system of the State Sao Paulo in Brazil. Building and Environment, 42, 984999.

http://doi.org/10.1016/j.buildenv.2005.10.020

Darkwa, I. (2006). Post-occupancy evaluation of state-subsidised housing units in Kayamandi, Stellenbosch [PhD Thesis]. University of Stellenbosch.

Eley, J. (2001). How do post-occupancy evaluation and the facilities manager meet? Building Research \& Information, 29(2), 164-167. http://doi.org/10.1080/09613210010016848

Gill, Z. M., Tierney, ichael J., Pegg, I. M., \& Allan, N. (2010). Low-energy dwellings : the contribution of behaviours to actual performance. Building Research \& Information, 38(5), 491-508. http://doi.org/10.1080/09613218.2010.50537 1

Goh, A. T., \& Ahmad, Y. (2012). Public LowCost Housing In Malaysia : Case Studies On Ppr Low-Cost Flats In Kuala Lumpur. Kuala Lumpur. Retrieved from fbe.um.edu.myimagesfabFilesjdbevol8vol801.pdf MALAYSIA

Goh, Y. M., Love, P. E. D., Stagbouer, G., \& Annesley, C. (2012). Dynamics of safety 
performance and culture: A group model building approach. Accident; Analysis and Prevention, 48, 118-25. http://doi.org/10.1016/j.aap.2011.05.010

Government of Malaysia. (2016). 11th Malaysia plan (2016-2020).

Gupta, R., \& Chandiwala, S. (2010). Understanding occupants : feedback techniques for large-scale low-carbon domestic refurbishments. Building Research \& Information, 38(5), 530-548. http://doi.org/10.1080/09613218.2010.49521 6

Hashim, A. H. (2003). Residential Satisfaction and Social Integration in Public Low Cost Housing in Malaysia. Pertanika Journal of Social Science \& Humanities, Universiti Putra Malaysia Press, 11(1), 1-10.

Hassanain, M. A. (2007). Post-Occupancy Indoor Environmental Quality Evaluation of Student Housing Facilities. Architectural Engineering and Design Management, 3(4), 249-256.

Hirning, M. B., Isoardi, G. L., Coyne, S., Garcia Hansen, V. R., \& Cowling, I. (2012). Post occupancy evaluations relating to discomfort glare: A study of green buildings in Brisbane. Building and Environment, 1-9. http://doi.org/10.1016/j.buildenv.2012.08.032

Ho, D. C.-W., Chau, K.-W., King-Chung Cheung, A., Yau, Y., Wong, S.-K., Leung, H.-F., ... Wong, W.-S. (2008). A survey of the health and safety conditions of apartment buildings in Hong Kong. Building and Environment, 43(5), 764-775. http://doi.org/10.1016/j.buildenv.2007.01.035

Idrus, N., \& Ho, C. S. (2008). Affordable And Quality Housing Through The Low Cost Housing Provision In Malaysia. In Seminar of Sustainable Development and Governance, Department of Civil Engineering, and Architecture, Toyohashi University of Technology, 26 June 2008 (pp. 1-21).

Ismail, E. (2003). Achieving Quality In Housing Construction Through Standardisation. In 2nd Asian Forum Conference Tokyo (20 - 23 January 2003). Tokyo, Japan: Institute of International Harmonisation For Building and Housing. Retrieved from http://www.asian-

forum.net/conference_2003/presenter_pdf/M alaysia_01PAP.pdf

Jacomit, A. M., \& Granja, A. D. (2011). An Investigation into the Adoption of Target Costing on Brazilian Public Social Housing Projects. Architectural Engineering and Design Management, 7(2), 113-127. http://doi.org/10.1080/17452007.2011.58233 4
Junaidi, A. B., Fauzi, R., \& Ghazali, A. S. (2012). Penilaian awal impak perlaksanaan Dasar Perumahan Negara terhadap sektor perumahan di Kuala Lumpur. GEOGRAFIA Online Malaysia Journal of Society and Space, 6(6), 90-108.

Karemera, D., Reuben, L. J., \& Sillah, M. R. (2003). The effects of academic environment and background characteristics on students' satisfaction and performance: The Case of South Carolina State University's School of Business. College Student Journal, 37(2), 298-311. Retrieved from http://ezproxy.um.edu.my:2062/login.aspx?di rect $=$ true $\& d b=a p h \& A N=10049293 \&$ site $=e h$ ost-live

Khalil, N., \& Husin, H. N. (2009). Post Occupancy Evaluation towards Indoor Environment Improvement in Malaysia' s Office Buildings. Journal of Sustainable Development, 2(1), 186-191.

Khalil, N., \& Nawawi, A. H. (2008). Performance Analysis of Government and Public Buildings via Post Occupancy Evaluation. Asian Social Science, 4(9), 103112.

Kim, S. S. S., Yang, I. I. H., Yeo, M. M. S., \& Kim, K. K. W. (2005). Development of a housing performance evaluation model for multi-family residential buildings in Korea. Building and Environment, 40(8), 11031116. http://doi.org/10.1016/j.buildenv.2004.09.014

Kowaltowski, C. C. K. D., Da Silva, V. G., Pina, S. A. M. G., Labaki, L. C., Ruschel, R. C., \& Moreira, D. de C. (2006). Quality of life and sustainability issues as seen by the population of low-income housing in the region of Campinas, Brazil. Habitat International, 30, 1100-1114. http://doi.org/10.1016/j.habitatint.2006.04.00 3

Krejcie, R. V, \& Morgan, D. W. (1970). Determining sample size. Educational and Psychological Measurement, 38, 607-610.

Leung, M. Y., Yu, J., \& Memari, A. (2016). Managing Indoor Facilities In Public Housing To Improve Elderly Quality Of Life. Int. Journal for Housing Science, 40(2), 8599.

Lim, C. K., Rabindra, N. Sen, Ahmad Rafi, M. E., Choon, L. I. M., Nath, R., Rafi, A., \& Eshaq, M. (2001). Ergonomic and architectural designs: development to improve residential low-cost housing in Malaysia.

Liu, A. M. M. (2003). The quest for quality in public housing projects: a behaviour-tooutcome paradigm. Construction Management and Economics, 21, 147-158. 
http://doi.org/10.1080/014461903200004970 0

Minami, K. (2007). A Post-Occupancy Evaluation of Layout Changes Made to KEP Adaptable Housing. Journal of Asian Architecture and Building Engineering (JAABE), 6(2), 245-250.

Ministry of Finance Malaysia. (2016). Malaysia's Budget 2016. Retrieved from http://www.treasury.gov.my/pdf/budget/spee ch/bs16.pdf

Mohit, M. A., Ibrahim, M., \& Rashid, Y. R. (2010). Assessment of residential satisfaction in newly designed public low-cost housing in Kuala Lumpur , Malaysia. Habitat International, $34(1), \quad 18-27$. http://doi.org/10.1016/j.habitatint.2009.04.00 2

Mohit, M. A., \& Nazyddah, N. (2010). Assessment of residential satisfaction with low-cost housing provided by Selangor Zakat Board in Malaysia. In V. Randolph, B., Burke, T., Hulse, K. and Milligan (Ed.), 4th Australasian Housing Researchers Conference, Sydney, 5th - 7th August 2009 (pp. 1-26). Retrieved from http://www.fbe.unsw.edu.au/cf/apnhr/

Muhamad Ariff, N. R. (2011). Effective Housing Management Framework For Multi-Owner Low-Cost Housing In Malaysia [PhD Thesis]. Deakin University, Australia.

Mumovic, D., Davies, M., Ridley, I., Altamirano-Medina, H., \& Oreszczyn, T. (2009). A methodology for post-occupancy evaluation of ventilation rates in schools. Building Serv. Eng. Res. Technol., 30(2), 143-152.

Mustafa, F. A. (2017). Performance assessment of buildings via post-occupancy evaluation: A case study of the building of the architecture and software engineering departments in Salahaddin. Frontiers of Architectural Research http://doi.org/10.1016/j.foar.2017.06.004

Nicol, F., \& Roaf, S. (2005). Post-occupancy evaluation and field studies of thermal comfort. Building Research \& Information, 33(4), 338-346. http://doi.org/10.1080/09613210500161885

Olanrewaju, A. L. (2010). Case for alternative approach to building maintenance management of public universities. Journal of Building Appraisal, 5(3), 201-212. http://doi.org/10.1057/jba.2009.19

Osei-poku, G. (2016). Post Occupancy Evaluation of the Ahanta Hall of Takoradi Polytechnic, Ghana. Greener Journal of Science, Engineering and Technological Research, 6(2), 40-47. http://doi.org/10.15580/GJSETR.2016.2.050
416083

Pati, D., Park, C.-S., \& Augenbroe, G. (2006). Roles of building performance assessment in stakeholder dialogue in AEC. Automation in Construction, 15, 415-427. http://doi.org/10.1016/j.autcon.2005.06.009

Pitt, M., \& Tucker, M. (2008). Performance measurement in facilities management: driving innovation? Property Management, 26(4), 241-254. http://doi.org/10.1108/02637470810894885

Preiser, W. F. (2001). Feedback, feedforward and control: post-occupancy evaluation to the rescue. Building Research \& Information, 29(6) 456-459. http://doi.org/10.1080/09613210110072692

Rashid, Y. R. (2008). Housing Satisfaction Perceived By The Residents Of Projek Perumahan Rakyat ( PPR ) Sungai Bonus In Setapak, Kuala Lumpur.

Said, N. S., \& Juanil, D. M. D. (2013). The Housing Environment Preference Among Housing Consumers in Johor Bahru. In 2nd International Conference on Technology Management , Business and Entrepreneurship (pp. 55-70). Mahkota Hotel Melaka Malaysia (5th December 2013).

Salleh, A. G., \& Yusof, N. (2006). Residential Satisfaction In Low-Cost Housing In Malaysia. Universiti Sains Malaysia (USM), Penang, Malaysia.

Shahrom, S. K., \& Zainol, R. (2015). Universal design in housing for people with disabilities: A review. Journal of Design and Built Environment, 15(1), 33-42. Retrieved from https://ejournal.um.edu.my/index.php/jdbe/ar ticle/view/5351/3136

Stevenson, F., \& Leaman, A. (2010). Evaluating housing performance in relation to human behaviour: new challenges. Building Research \& Information, 38(5), 437-441. http://doi.org/10.1080/09613218.2010.49728 2

Vilcekova, S., Meciarova, L., Burdova, E. K., Katunska, J., Kosicanova, D., \& Doroudiani, S. (2017). Indoor environmental quality of classrooms and occupants' comfort in a special education school in Slovak Republic. Building and Environment, 120(2017), 2940.

http://doi.org/10.1016/j.buildenv.2017.05.001

Vischer, J. C. (2008). Towards a user-centred theory of the built environment. Building Research \& Information, 36(3), 231-240. http://doi.org/10.1080/09613210801936472

Wang, S. T., Ho, D. C. W., \& Chen, W. (2005). An introduction to the health concern in the Dwelling Performance Rating System in Mainland China, in E.H.W. Chan and 
D.C.W. Ho (eds.). In Proceeding of CII-HK

Conference 2005 on Healthy Building,

Community Health and the Built

Environment (pp. 95-108). Construction

Industry Institute, Hong Kong.

Way, M., \& Bordass, B. (2005). Making feedback and post-occupancy evaluation routine 2: Soft landings - involving design and building teams in improving performance. Building Research \& Information, 33(4), 353-360. http://doi.org/10.1080/09613210500162008

Yau, Y. (2005). Comparative Study Of Building Performance Assessment Schemes In Hong Kong Performance Assessment. Hong Kong Surveyor, 16(1), 47-58.

Yau, Y. (2006). The Safety Performance of Apartment Buildings: Empirical Evidence from Hong Kong [PhD Thesis]. The University of Hong Kong.

Zimmerman, A., \& Martin, M. (2001). Postoccupancy evaluation: benefits and barriers. Building Research \& Information, 29(2), 168-174.

http://doi.org/10.1080/09613210010016857 